\title{
Outcome of Mass Abdominal Fascial Closure in Midline Laparotomies: A Clinical Study at AVBRH
}

\author{
Dr Mazhar Aslam Dodhia, Dr Raju Kamlakarrao Shinde
}

\begin{abstract}
Objective: The study was focused to assess the outcome of the Mass closure in all midline laparotomy procedure regardless of the underlying condition and to understand the outcome. Materials and methods: A prospective study was carried out on 100 patients at a Rural Hospital undergoing midline laparotomy and the closure of abdomen was performed by a non absorbable polypropylene (Prolene) suture material, in a continuous Mass closure technique followed by the rate of incidence of development of complications like surgical site infection, wound dehiscence (partial or complete) and incisional hernia were assessed and correlated with the patient related factors. Results: Surgical site infection was the most common complication encountered, followed by incisional hernia and wound dehiscence. Hypoproteienemia was significantly associated with the incidence of complications. Surgical site infection has a strongly significant association, with the incidence of development of incisional hernia as well as wound dehiscence. Conclusion: Continuous mass closure is the ideal technique for the closure of the abdomen with a non-absorbable polypropylene suture material, in the absence of patient confounding factors like hypoproteinemia and surgical site infection.
\end{abstract}

Keywords: Midline laparotomy, mass closure, Incisional hernia, wound dehiscence, surgical site infection

\section{Introduction}

Wound healing is the restoration of tissue continuity after injury. ${ }^{1}$ The goal of wound closure is to restore the function of the abdominal wall after a surgical procedure. The optimal method should be so technically simple that its results are as good for the hands of the trainee as they are for the experienced surgeon. It should leave the patient with a reasonably aesthetic scar, and most importantly, it should minimize the frequency of wound rupture, incisional hernia, wound infection, and sinus formation.

The primary complications or failure of the wound closure are wound dehiscence, wound herniation/incisional hernia and wound infection. ${ }^{2}$

The Literature shows numerous studies to find the ideal technique for the abdominal wall closure. The studies have precisely pointed over the issues encountered with different types of incisions, suture materials and suturing methods, which have affected the outcome of the closure significantly.

Cyedali et alperformed a medline search to find out the most effective method of midline abdominal fascial closure. He came to a conclusion that the most effective method of midline abdominal fascial closure involves mass closure, incorporating all of the layers of the abdominal wall (except skin) as 1 structure, in a simple running technique, with \#1 or \#2 absorbable monofilament suture material with a suture length to wound length ratio of 4 to $1 .^{3}$

Yet, when comparing these studies still there is no common conclusion whether to use an absorbable or a non-absorbable suture. Various authors who have compared the continuous and interrupted suture techniques have concluded that the continuous sutures have an advantage of an evenly distributed tension across the suture line, being more expedient, fewer knots and stitch sinuses with an advantage of being a single suture line holding the fascia together. ${ }^{4,5}$

The value of a particular abdominal fascial closure technique may be measured by the incidence of early and late wound complications, and the best abdominal closure technique should be fast, easy, and cost- effective, while preventing both early and late complications. ${ }^{3}$

This study has been taken up to assess the outcome of the Mass closure in all midline laparotomy with a nonabsorbable suture material suture in a continuous technique regardless of the underlying condition and to understand the outcome. Since, it has been considered a far better method for the closure of abdomen when compared with layered method in the matter of time, cost and postoperative complication.

\section{Materials and Methods}

A prospective study was carried out from July 2014 to August 2016. The study consisted of 100 patients who underwent mass closure with midline laparotomy, attending the General Surgery outpatients, inpatients and casualty of Acharya Vinoba Bhave Rural Hospital, Sawangi (Meghe), Wardha, were enrolled in our study, diagnosed on history and clinical examination. The diagnosis was confirmed radiologically and/or histopatahologically as per the need. Patients who underwent laparotomy incisions other than midline vertical abdominal incisions and where retension sutures is an absolute indication were excluded from the study.In all the 100 patients, detailed history was obtained which was followed by a general systemic examination and a detailed abdominal evaluation.

Apart from the routine haematological investigations and assessment of the patients nutritional status, cases selected for our study were subjected to X-Ray abdomen (erect Ap view), USG abdomen pelvis and CECT abdomen pelvis

After the completion of the procedure undertaken closure was perfotmed polypropylene (Prolene) no. 1 suture on a round body needle. Length of suture was kept 4 times the length of the incision (4:1). Abdomen closed in a coutinuos mass closure technique. 


\section{International Journal of Science and Research (IJSR) \\ ISSN (Online): 2319-7064 \\ Index Copernicus Value (2015): 78.96 | Impact Factor (2015): 6.391}

\section{Procedure}

After performing surgical procedure as per the indication of laparotomy may be in an emergency or elective setting, Closure was done by No. 1 Monofilamental suture material (Prolene) of length 4 times the length of incision attached to round body needle.First Knots were taken at the proximal end of the incision with five square knots. The suture bite was placed $1 \mathrm{~cm}$ away from the edge of the incision and 1 $\mathrm{cm}$ away from the two adjacent sutures in a continuous fashion including peritoneum and linea alba and the terminal (Aberdeen) knot was taken at the other end of the incision and the knot was buried.Mattress skin sutures were taken by monofilament Non Absorbable Nylon sutures in intermittent fashion which was removed on 10th post operative day. Antibiotics were given as per indication of laparotomy and hospital antibiotic protocol for surgical site infection.

For each patient the status of the wound was evaluated post operatively on day $5^{\text {th }}, 10,21^{\text {st }}$ and $90^{\text {th }}$ for any complications.Statistical analysis was done by using descriptive and inferential statistics using Chi-square test.

Table 1: Baseline Age characteristic

\begin{tabular}{|c|c|c|}
\hline Age Group in years & $\begin{array}{c}\text { No of patients undergoing } \\
\text { midline laparotomy }\end{array}$ & $\begin{array}{c}\text { Percentage } \\
(\%)\end{array}$ \\
\hline $18-29$ & 12 & 12 \\
\hline $30-39$ & 22 & 22 \\
\hline $40-49$ & 20 & 20 \\
\hline $50-59$ & 21 & 21 \\
\hline $60-69$ & 16 & 16 \\
\hline$\geq 70$ & 9 & 9 \\
\hline Total & 100 & 100 \\
\hline Mean Age and SD & 46.9 years $\pm 15.44(19-80$ years $)$ \\
\hline
\end{tabular}

The present work was undertaken to study the outcome ofmass layered closure of midline abdominal incision. The study consisted of 100 patients who underwent midline laparotomy, meeting the inclusion criteria. Of the total of 100 patients, the youngest patient in our study was 18 years old while the eldest was 80 years with the mean age of $46.90 \pm$ 15.44years (Table No.1).8 cases developing incisional hernia, $3(37.50 \%)$ patients were in their $4^{\text {th }}$ decade of life. Followed by, $2(25 \%)$ patients each in their $5^{\text {th }}$ and $6^{\text {th }}$ decade of life. $1(12.5 \%)$ patient belonged to the $3^{\text {rd }}$ decade of his life. The young patients in the $2^{\text {nd }}$ and those in $7^{\text {th }}$ and $8^{\text {th }}$ decade of life had no reported case of incisional Hernia.65 (65\%) patients were males and $35(35 \%)$ patients were females thus the male to female ratio was $1.85: 1$. Out of total $65(65 \%)$ male patients, $37(56.9 \%)$ patients underwent elective midline laparotomy and the rest, 28 (43.1\%) patients underwent emergency midline laparotomy. Out of 35 female patients, $23(65.7 \%)$ cases underwent elective midline laparotomy and 12 (34.3\%) cases underwent emergency midline laparotomy. Patients those underwent elective midline laparotomy, Preoperatively, $19(31.66 \%)$ patients were diagnosed with colon carcinoma. Out of which there were 12 male patients and 7 female patients. There were $14(23.30 \%)$ patients of liver Hydatid cyst of them, 9 were male and 5 female. 9(15.\%) patients with stomach carcinoma showed higher incidence in females. $7(11.6 \%)$ patients in the study diagnosed with Carcinoma of Rectum. During our study, three cases (5\%) of each Gastric Outlet Obstruction \& Carcinoma of the Pancreas were included, two $(3.33 \%)$ cases of Gastro Intestinal Stromal Tumor and one $(1.67 \%)$ case each of Tuberculous pancreatitis , Carcinoid Tumor and Carcinoma Anal Canal also underwent elective midline laparotomy.(Graph No 1)majority of patients 19 (47.5\%), operated during an emergency were diagnosed as perforation peritonitis with a higher incidence in males. In $14(35 \%)$ patients operated for intestinal obstruction, 8 were males and 6 patients were females. Remaining $4(10 \%)$ patients were diagnosed as sigmoid volvulus and $3(7.5 \%)$ cases were of penetrating trauma over the abdomen. (Graph No. 2). During our study, all the patients were subjected for a complete haemogram. They were divided into two groups. Group 1 consisted of patients with haemoglobin less than or equal to $10 \mathrm{gm} / \mathrm{dl}$ and group two comprising of patients with haemoglobin more than $10 \mathrm{gm} / \mathrm{dl}$. $28 \%$ patients were grouped as group 1 and remaining were included in group 2.The patients in group 1 received preoperative, intraoperative and postoperative blood transfusion as per the indication. a detailed history and thorough systemic evaluation was done for all patients. Associated condition predisposing to Incisional hernia \& wound Dehiscence were Coronary Artery Disease in 12 patients, Hypertension in 12 patient, Diabetes Mellitus in 06 patients, Tuberculosis in 07 patients, COPD in 04 patients, Hypertension with Diabetes Mellitus in 11, Tuberculosis with COPD in 04 patients, HTN with Diabetes Mellitus with COPD in 02 patients, Diabetes Mellitus with Coronary Artery Disease in 01 patient, Hypertension with Diabetes Mellitus with Coronary Artery Disease in 04 patients, Diabetes Mellitus with Tuberculosis in 04 patients. There were 33 patients in our study who had no co morbidities. , Patients were even tabulated as per the location of midline incisions out of 100 patients, $38(38 \%)$ patients were operated with upper midline incision, 04(10.52\%) developed Superficial Surgical Site Infection and $04(10.52 \%)$ developed Incisional Hernia, $12(12 \%)$ patients received lower midline incision $1(8.3 \%)$ developed SSI, none developed Incisional Hernia throught the lower midline incision and $50(50 \%)$ patients received midline incision extending from upper abdomen to lower abdomen that is combined incision (Table No. 2). , only $1(2 \%)$ patient out of the 50 cases operated by the Combined midline incision developed SSI with Abdominal Rectus wound dehiscence. $10(20 \%)$ cases were reported of Surgical Site Infection limited up to skin and subcutaneous tissue. 4(8\%) cases, developed incisional hernia. How ever the P value for both SSI and Incisional Hernia Stood insignificant when associated with the type of incision..$\{\times 2=2.7112$ $\mathrm{P}=0.257792$, not significant, $\mathrm{P}<0.05\}$ and $\{\mathrm{x} 2=1.373$ $\mathrm{P}=0.503335$, not $\mathrm{S}, \mathrm{P}<0.05\}$. 


\section{International Journal of Science and Research (IJSR) \\ ISSN (Online): 2319-7064}

Index Copernicus Value (2015): 78.96 | Impact Factor (2015): 6.391

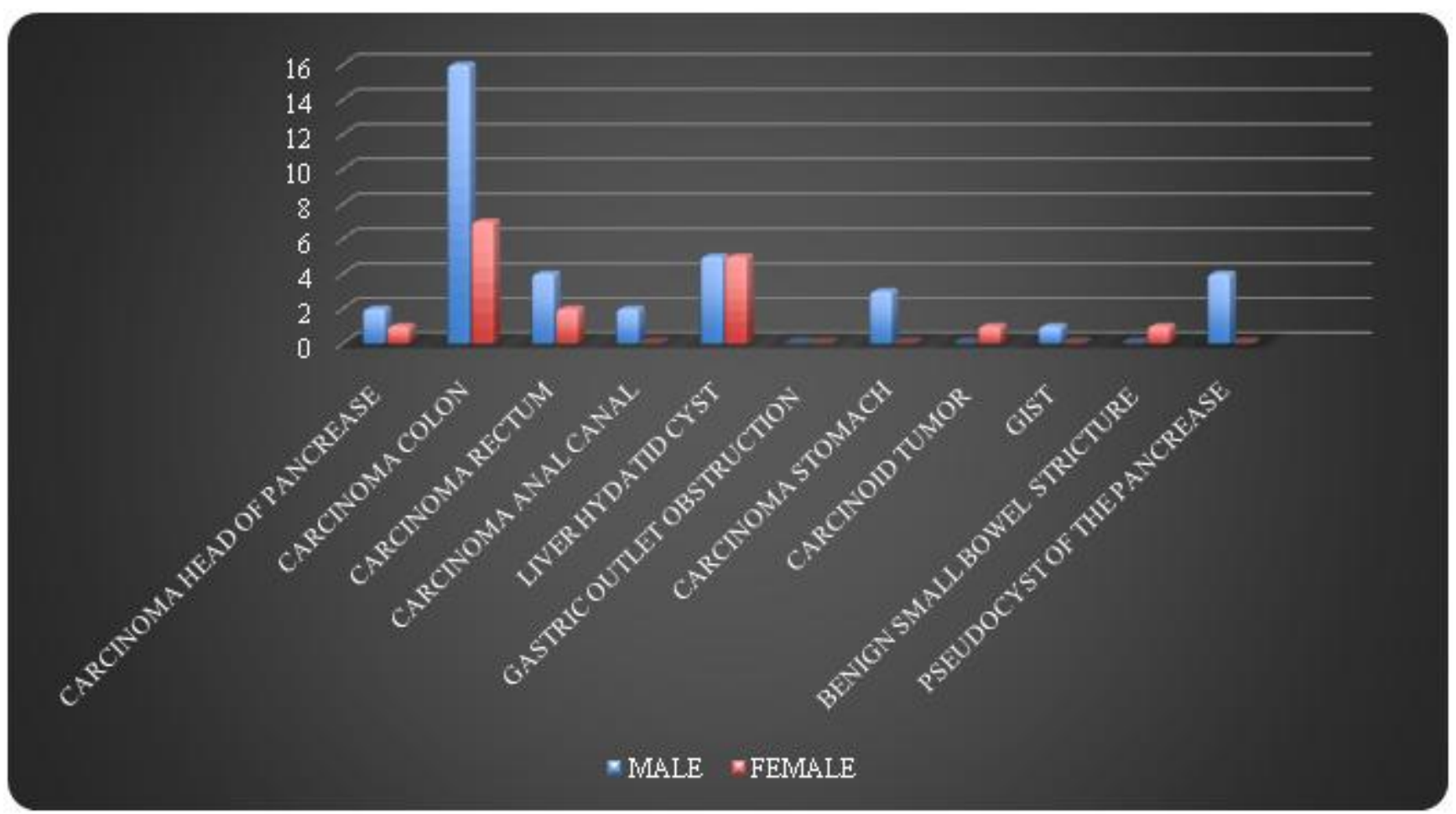

Graph 1: Distribution of Patients according to clinical diagnosis, who underwent elective midline laparotomy

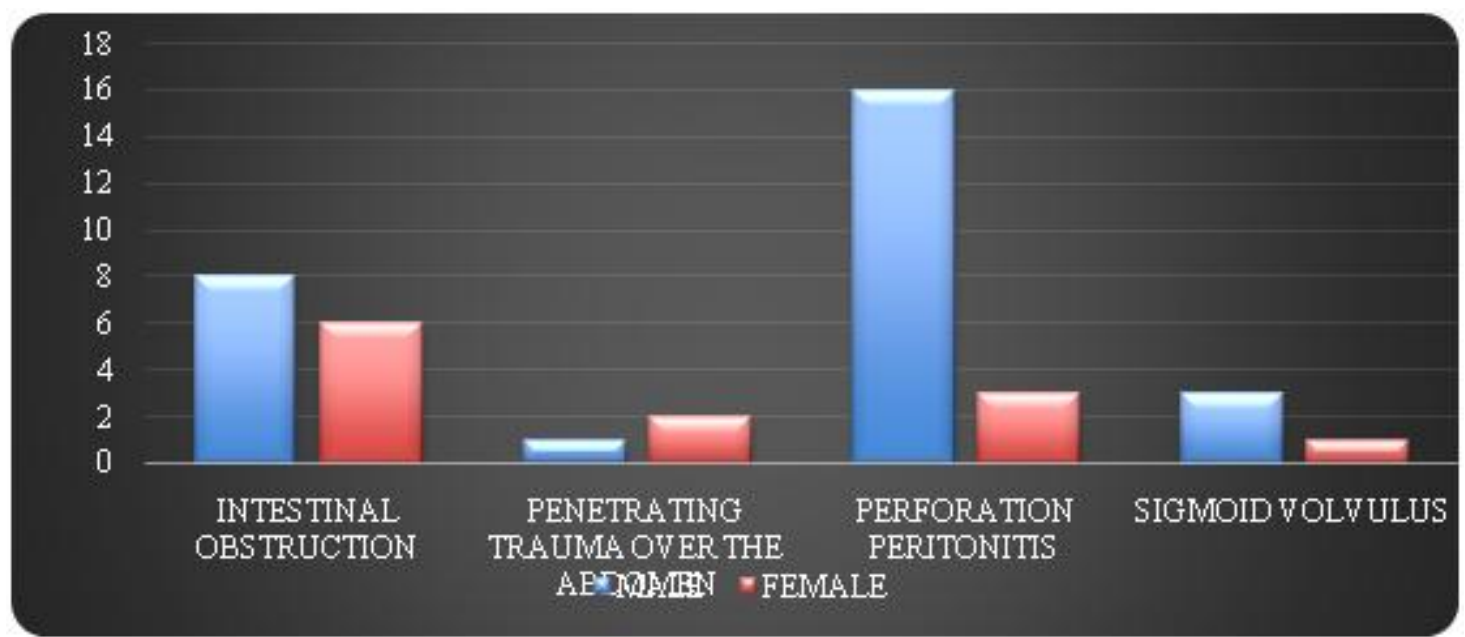

Graph 2: Distribution of Patients according to clinical diagnosis, who underwent emergency midline laparotomy

Table 2: Distribution of patients according to the Midline Incision.

\begin{tabular}{|l|c|c|}
\hline Incision & No of patients & Percentage(\%) \\
\hline Upper Midline & 38 & 38 \\
\hline Lower Midline & 12 & 12 \\
\hline Combined Incision & 50 & 50 \\
\hline
\end{tabular}

Table 3: Distribution of patients as per the complications encountered

\begin{tabular}{|c|c|c|c|}
\hline $\begin{array}{c}\text { Surgical Site Infection without Abdominal Rectus } \\
\text { Dehisence }\end{array}$ & 6 & 9 & 15 \\
\hline $\begin{array}{c}\text {-Surgical Site Infection with Abdominal Rectus } \\
\text { Dehiscence (Partial/complete) }\end{array}$ & 1 & 0 & 1 \\
\hline Incisional Hernia within 3 months sequel to SSI & 2 & 3 & 5 \\
\hline Incisional Hernia with out SSI prequel & 1 & 2 & 3 \\
\hline Uneventful postoperative period & 52 & 29 & 81 \\
\hline
\end{tabular}

Amongst those 60 patients which underwent elective procedure, 7 (11.6\%) developed surgical site infection, of those patients who developed SSI, 6 (10\%) Surgical Site
Infection with out Abdominal Rectus Dehiscence and 1 (1.66\%) patient Developed Surgical Site Infection with Abdominal Rectus Dehiscence, The reported cases of incisional hernia of those undergone elective midline laparotomy was $3(5 \%)$ patients who developed incisional hernia, $2(3.33 \%)$ patients had a prequel episode of surgical site infection limited to the Skin and Subcutaneous tissue, $1(1.66 \%)$ had no such episode of SSI, however 52(86.66\%) patients had an uneventful postoperative period. None of the patients developed burst abdomen(complete dehiscence) during our study.(Table No. 3)

The remaining 40 cases who were subjected to emergency midline laparotomy, out of which $9(22.5 \%)$ developed surgical site infection all the 9 cases had superficial incisional SSI. 5(12.5\%) patients of the 40 cases of emergency midline laparotomy developed incisional hernia. Of those $5(12.5 \%)$ cases of incisional Hernia 3(7.5\%) patients had a prequel episode of Surgical site infection

\section{Volume 6 Issue 1, January 2017




\section{International Journal of Science and Research (IJSR) \\ ISSN (Online): 2319-7064}

Index Copernicus Value (2015): 78.96 | Impact Factor (2015): 6.391

limited to the Skin and Subcutaneous tissue, the rest of the $2(5 \%)$ cases of incisional hernia had no such episode.

Rest of the $29(72.5 \% \%)$ patients had an uneventful postoperative period. None of the cases developed burst abdomen or abdominal (Rectus) wound dehiscence.(Table No.3)

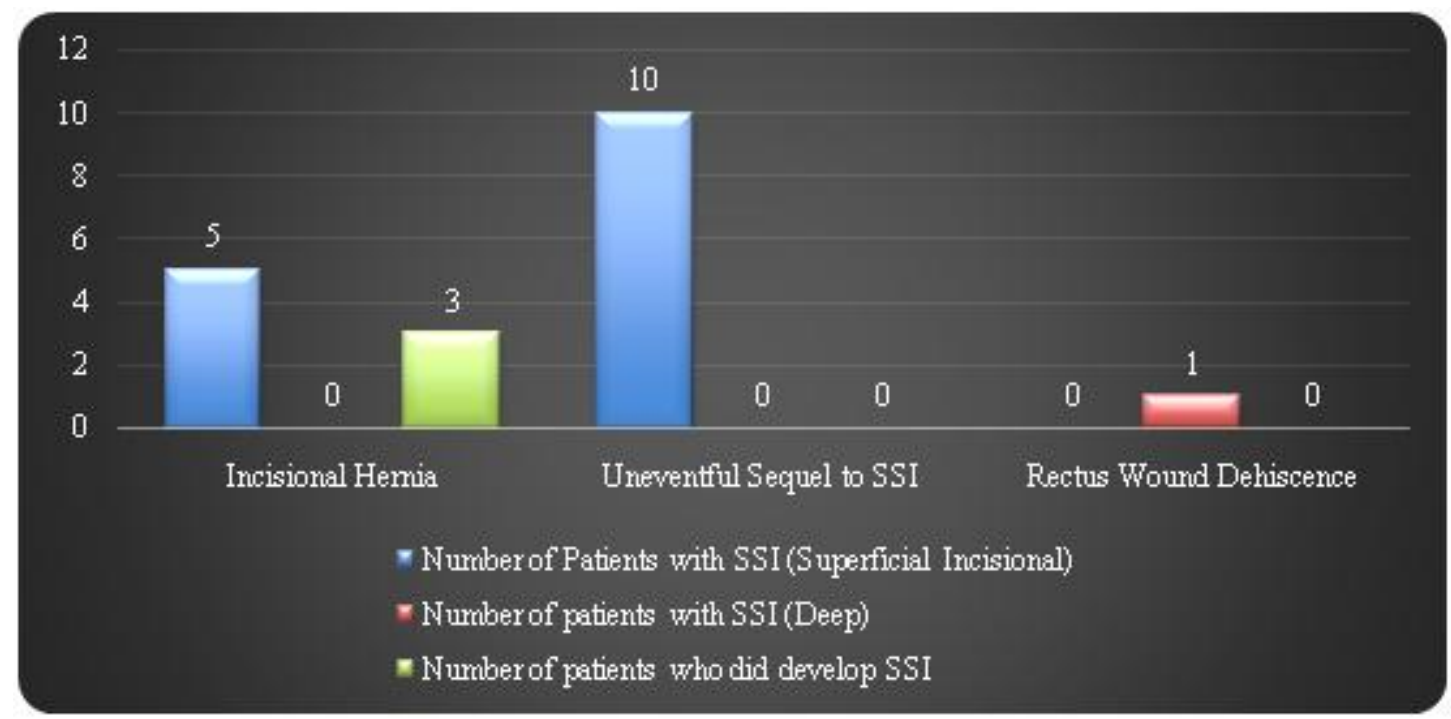

Graph 3: Association of incisional Hernia \& Abdominal Rectus Wound Dehiscence with Surgical Site Infection

In Our study a total of 16 cases had developed surgical site infection. The surgical site infection was categorized in to Grade of SSI, of those 15(93.75) patients developed Superficial Surgical Site infection and 1(7.75\%) patient developed Surgical site infection with dehiscence of Abdominal Rectus.

Of the 16 reported cases of Surgical Site infection, $5(31.25 \%)$, developed incisional hernia. 1 (6.25\%) developed Abdominal Rectus Wound dehiscence, the rest of the $10(62 \%)$ cases of Surgical site infection sequel was uneventful.3 cases of incisional hernia had no prequel of surgical site infection. The $\mathrm{P}$ value stands significant for the association of incisional hernia with surgical site infection. $\{\aleph 2=13.9897 \mathrm{P}=0.00184, \mathrm{~S}, \mathrm{P}<0.05\} \quad$ (graph 3$) .17(17 \%)$ patients were found to have hypoprotienemia during their post-operative hospital stay. All, the patients were managed as per the degree and indicated guidelines for management of hypoproteinemia.

Out of, those 17 patients with hypoproteinemia, 7(41.17\%) cases developed incisional hernia and 06(35.30\%) cases developed Surgical site infection (superficial) with out dehiscence of Abdominal Rectus. 1(5.8\%) patient developed partial dehiscence of the abdominal Rectus with out evisceration of the intra abdominal contents. Rest of the $10(58.9 \%)$ of hypoproteinemia showed no evidence of surgical site infection. And incisional hernia. The $P$ value stands out to be statistically significant for the association of Hypoproteinemia with Surgical site infection $\{\mathrm{x} 2=12.0516$ $\mathrm{P}=0.002416, \mathrm{~S}, \mathrm{P}<0.05\}$ and incisional hernia $\{\mathrm{N} 2=30.6305$ $\mathrm{P}=0.00001, \mathrm{~S}, \mathrm{P}<0.05\}$.

\section{Discussion}

Acute wound failure is one of the major complications following laparotomy with significant morbidity and mortality. The prevalence of disease has varied with time and geographical location. In the Asian countries the incidence of abdominal wound dehiscence is still very high and stays above $10 \%$ level due to widely prevalent malnutrition and the lack of proper health care delivery system providing the surgical treatment. The operation at the rural and suburban level may be often delayed for a day or more resulting in much tissue necrosis of the linea alba as well as more marked systemic inflammatory response syndrome adversely affecting healing and collagen synthesis especially in cases of peritonitis ${ }^{6}$ Of the total of 100 patients, the youngest patient in our study was 19 years old while the eldest was 80 years with the mean age of $46.90 \pm 15.44$ years.

Table 4: Incidence of age group undergoing laparotomy

\begin{tabular}{|c|c|c|c|}
\hline Author & Year & Place & $\begin{array}{c}\text { Highest incidence in } \\
\text { age group (years) }\end{array}$ \\
\hline Singh et al $^{7}$ & 2014 & Pune & $61-70$ \\
\hline Chalya et al $^{8}$ & 2015 & Tanzania & $31-40$ \\
\hline Graham et al $^{9}$ & 2016 & Tamilnadu & $31-40$ \\
\hline Present study & 2016 & Wardha & $30-49$ \\
\hline
\end{tabular}

- Out of 100 patients, $65(65 \%)$ patients were males and 35 (35\%) patients were females thus the male to female ratio was $1.85: 1$. In a study by Chalya et al, 872 patients underwent elective midline laparotomy with the male to female ratio of $2.8: 1^{8} \mathrm{In}$ a study by Ibrahim et al. the male to female ratio was $2.1: 1^{10}$ The ratio was found to be much higher in Gurjar et al.'s study of comparison of two different techniques of midline laparotomy, the male to female ratio was 8.09:1 \& 5.66:1 in either of the groups. ${ }^{10}$ The male predominance for Midline laparotomies seems to be due to their professional, personal and behavioral life style, making them more prone to acute as well as chronic abdominal conditions. In this study, out of 100 patients, $33(33 \%)$ patients were operated with upper midline incision, $13(13 \%)$ patients received lower midline incision and $54(54 \%)$ patients received midline incision extending from upper abdomen to lower

\section{Volume 6 Issue 1, January 2017




\section{International Journal of Science and Research (IJSR) \\ ISSN (Online): 2319-7064}

Index Copernicus Value (2015): 78.96 | Impact Factor (2015): 6.391

abdomen. Chalya et al. in his study of elective midline laparotomies in 872 cases, took midline incision in 644 $(73.9 \%)$ patients, lower (sub-umbilical) midline incisions (SUMI) in $214(24.5 \%)$ patients and upper midline incisions in $14(1.6 \%)$ patients. ${ }^{8}$ Richard et al. in his study of 571 patients, divided the patients for midline incisions as upper, lower and combined incision (xiphoid to pubis). Majority of the 298 patients received upper midline incision followed by lower midline incision in 97 patients.

${ }^{12}$ The choice of incision depends on the surgeon \& the overall indication of laparotomy. Usually the midline incisions are extended cranio-caudally for a better exposure of the abdominal cavity.

Over all Incidence of the post operative complications including the incidence of surgical site infection, abdominal rectus wound dehiscence (both partial and complete), incisional hernia from various studies has been tabulated below, regardless of the technique used for the closure of the abdomen .

Table 5: Comparison of Incidence of complications with other studies

\begin{tabular}{|c|c|c|c|c|c|}
\hline Author \& Suture Material used & Year & $\begin{array}{l}\text { Incidence of Surgical } \\
\text { Site Infection }\end{array}$ & $\begin{array}{l}\text { Incidence of Abdominal Rectus } \\
\text { Wound Dehisence/Burst Abdomen }\end{array}$ & $\begin{array}{c}\text { Incidence of } \\
\text { Incisional Hernia }\end{array}$ & Follow Up \\
\hline $\begin{array}{c}\text { Mirza et al. } \\
\text { Polydiaxanone Polypropylene }\end{array}$ & 2003 & \begin{tabular}{|l|}
$10.12 \%$ \\
$11.76 \%$ \\
\end{tabular} & $\begin{array}{l}1.26 \% \\
2.35 \% \\
\end{array}$ & $\begin{array}{l}5.06 \% \\
4.70 \% \\
\end{array}$ & 12 Months \\
\hline Marwah et al ${ }^{14}$ & 2005 & NR & 225 & $24 \%$ & 6 Months \\
\hline $\begin{array}{l}\text { Ducobo- Durantez } \\
\text { Polydiaxone Nylon }\end{array}$ & 2006 & $\begin{array}{l}4.65 \% \\
6.26 \%\end{array}$ & $\begin{array}{c}0.88 \% \\
0.626 \%\end{array}$ & $\begin{array}{c}7.69 \% \\
4.7 \%\end{array}$ & 18 Months \\
\hline $\begin{array}{c}\text { Seiler et al. }{ }^{16} \\
\text { Vicryl polydioxanone } \\
\text { Monoplus }\end{array}$ & 2009 & $\begin{array}{l}12.7 \% \\
19.4 \% \\
16.3 \%\end{array}$ & $\begin{array}{l}2.0 \% \\
3.0 \% \\
4.0 \%\end{array}$ & $\begin{array}{c}15.9 \% \\
8.4 \% \\
12.5 \%\end{array}$ & 12 Months \\
\hline $\begin{array}{c}\text { Mutraza et al. }{ }^{17} \\
\text { (prolene) }\end{array}$ & 2010 & $33.3 \%$ & $2.77 \% / 0.5 \%$ & $2.7 \%$ & 23 Months \\
\hline $\begin{array}{c}\text { Bloeman et al. }{ }^{18} \\
\text { Polydiaxanone Polypropylene }\end{array}$ & 2011 & $\begin{array}{c}6.74 \% \\
5.4 \% \\
\end{array}$ & $\begin{array}{l}6.74 \% \\
3.51 \% \\
\end{array}$ & $\begin{array}{l}21.72 \% \\
17.57 \% \\
\end{array}$ & 36 Months \\
\hline $\begin{array}{c}\text { Gurjar et al. } \\
\text { Prolene } \\
\end{array}$ & 2012 & $11.5 \%$ & $04 \%$ & $04 \%$ & 36 Months \\
\hline $\begin{array}{c}\text { Ibrahim et al. }^{10} \\
\text { Vicryl }\end{array}$ & 2014 & $29.6 \%$ & $0.5 \%$ & $0.5 \%$ & 12 Months \\
\hline $\begin{array}{c}\text { Mali karjun et al. }{ }^{19} \\
\text { (prolene -cont-) prolene-interrupted } \\
\text { Polyhydroxybutyrate }\end{array}$ & 2015 & $\begin{array}{l}14.70 \% \\
15.38 \% \\
16.66 \% \\
\end{array}$ & $\begin{array}{l}3.92 \% \\
3.29 \% \\
3.84 \% \\
\end{array}$ & $\begin{array}{l}12.74 \% \\
13.18 \% \\
6.41 \% \\
\end{array}$ & 12 Months \\
\hline $\begin{array}{c}\text { Chalya et al. }^{8} \\
\text { (overall incidence) }\end{array}$ & 2015 & $11.23 \%$ & $2.75 \%$ & $2.06 \%$ & 24 Months \\
\hline $\begin{array}{l}\text { Graham et al. }{ }^{9} \\
\text { (prolene) }\end{array}$ & 2016 & $18 \%$ & $9 \% / 1 \%$ & $2 \%$ & 6 Months \\
\hline Present Study & 2016 & $16 \%$ & $1 \% / 0 \%$ & $8 \%$ & Months \\
\hline
\end{tabular}

In Our study a total 16 cases had developed surgical site infection. The surgical site infection was categorized in to Grade of SSI, Of those 15(93.75) patients developed Superficial Surgical Site infection and 1(7.75\%) patient developed Surgical site infection with dehiscence of Abdominal Rectus. Of the 16 reported cases of Surgical Site infection, 5(31.25\%), developed incisional hernia. 1 (6.25\%) developed Abdominal Rectus Wound Dehiscence, the rest of the $10(62 \%)$ cases of Surgical site infection sequel was uneventful. cases of incisional hernia had no prequel of surgical site infection. The $\mathrm{P}$ value stands significant for the association of incisional hernia and abdominal rectus dehiscence with surgical site infection. $\{\mathrm{N} 2$ $=13.9897 \mathrm{P}=0.00184, \mathrm{~S}, \mathrm{P}<0.05\}$ Carlson Et al. in his study reported 6 patients of the 70 patients who encountered surgical site infection superficial and deep developed ventral incisional hernia. He even reported of the 13 patient who encountered wound dehiscence (partial or complete), 1 patient of them developed Incisional hernia in his study. ${ }^{20}$ Richards et al. in his study of 571 patients encountered 8 cases of wound dehiscence (partial or complete with or without evisceration), of those 3 cases had developed Surgical site infection superficial or deep and 5 cases had no incidience of SSI. There were a total 23 reported cases if surgical site infection in his study. The $P$ value stood statistically significant. However, he did not encounter any case of Incisional hernia with a prequel of surgical site infection in his study. ${ }^{12}$ In our study, out of $100(100 \%)$ cases operated, $17(17 \%)$ patients were found to have hypoprotienemia during their post-operative hospital stay. All, the patients were managed as per the degree and indicated guidelines for management of hypoproteinemia. Out of, those 17 patients with hypoproteinemia, 7(41.17\%) cases developed incisional hernia. Rest of the $10(58.90 \%)$ patients with hypoproteinemia did not show any signs of incisional Hernia with in the 3 months follow up period. $\{\times 2$ $=30.6305 \mathrm{P}=0.00001, \mathrm{~S}, \mathrm{P}<0.05\}$. Murariu et al. in his study of causes of recurrent incisional hernia of the 735 patients included in his study, reported 47 cases $(6.4 \%)$ where found to be suffering from hypoproteinemia. ${ }^{21}$ Spencer et al in his study of 265 laparotomies also reported that, one of the primary risk factor for incisional hernia development is Poor nutritional status ( albumin less than $3 \mathrm{gm} / \mathrm{dl}$ ). ${ }^{22}$ In the present study, out of $100(100 \%)$ cases operated, $17(17 \%)$ patients were found to have hypoprotienemia during their post-operative hospital stay. Out of, those 17 patients with hypoproteinemia, 06(35.30\%) cases developed Surgical site infection(superficial) with out Dehiscence of Abdominal Rectus. $1(5.8 \%)$ patient developed partial dehiscence of the abdominal Rectus with out evisceration of the intra abdominal contents. . Rest of the 10(58.9\%) of hypoproteinemia showed no evidence of surgical site

\section{Volume 6 Issue 1, January 2017




\section{International Journal of Science and Research (IJSR) \\ ISSN (Online): 2319-7064 \\ Index Copernicus Value (2015): 78.96 | Impact Factor (2015): 6.391}

infection. Of the rest of the $83(83 \%)$ patients who did not develop hypoproteinemia during the peri or post operative period, of those $9(10.84 \%)$ developed surgical site infection (superficial) while the rest of the $74(83.16 \%)$ did not encounter surgical site infection. The $\mathrm{P}$ value stands out to be statistically significant for the association of Hypoproteinemia with Surgical site infection. $\{\mathrm{N} 2=12.0516$ $\mathrm{P}=0.002416, \mathrm{~S}, \mathrm{P}<0.05\}$. Graham et al. reported 9 out of 100 patients in his study where suffering from hypoproteinemia, of those 9 patients of hypoproteinemia in his study 6 cases developed surgical site infection, 5 patients developed wound dehiscence, 1 developed Burst abdomen and 1 patient developed incisional hernia. ${ }^{9}$ Sorensen et at clearly states in his study that the Factors which are known to affect the process of tissue and wound healing are independently associated with tissue and wound complications following gastrointestinal surgery. Hypoproteinemia being considered as one of the major cause. ${ }^{23}$

\section{Conclusion}

Continuous mass closure is the ideal technique for the closure of the abdomen with a non-absorbable polypropylene suture material, in the absence of patient confounding factors like hypoproteinemia and surgical site infection. In our study, surgical site infection was the most common complication encountered, followed by incisional hernia and wound dehiscense. Hypoproteienemia was significantly associated with the incidence of complications. Surgical site infection has a strongly significant association, with the incidence of development of incisional hernia as well as wound dehiscence. However, the true incidence of incisional hernia cannot be drawn since the study was of short duration with a small sample size and without a long follow up.

\section{References}

[1] Goepel JR. Responses to cellular injury. In: Underwood JCE (ed.). General and systemic pathology, 2nd edn. London: Churchill Livingstone. 1996: 121-2

[2] DeLancey, J, Hartman, R, Glob. libr. women's med. (ISSN: $1756-2228) \quad 2008$; DOI 10.3843/GLOWM.10038

[3] Adil Ceydeli, MD, James Rucinski, MD, and Leslie Wise, MD Finding the Best Abdominal Closure: An Evidence-based Review of the Literature.. Department of Surgery, Weill Medical College of Cornell University and New York Methodist Hospital, Brooklyn, New York Volume 62/Number 2 • March/April 2005

[4] Bucknall TE, Cox PJ, Ellis H. Burst abdomen and incisional hernia: a prospective study of 1129 major laparotomies. Br Med J. 1982;284:931-933.

[5] Domball FT, Hill GL, Horrocks JC. A controlled clinical trial of three methods of closure of laparotomy wounds. Br J Surg 2005;62:823-9.

[6] Challa V, Dhar A, Anand S, Srivastava A. Abdominal wound dehiscence: the science and art of its occurrence and prevention. In: Gupta RL, editor. Recent advances in surgery-11. $1^{\text {st }}$ ed. New delhi:Jaypee Brothers; 2009.225-50.
[7] Singh G, Ahluwalia R. A comparison between mass closure and layered closure of midline abdominal incisions. Med J DY Patil Univ 2012;5:23-6.

[8] Phillipo L Chalya, Anthony N Massinde, Albert Kihunrwaand Joseph B MabulaAbdominal fascia closure following elective midline laparotomy: a surgical experience at a tertiary care hospital in Tanzania Chalya et al. BMC Res Notes (2015) 8:281 DOI 10.1186/s13104-015-1243-4

[9] Graham GRB, Vijayabhasker V. A prospective study of complications in emergency laparotomy. J. Evolution Med. Dent. Sci. 2016;5(12):513-519, DOI: $10.14260 /$ jemds/2016/118

[10] Ibrahim S. Elkheir et al. Evaluation of Abdominal Wall Closure Technique in Emergency Laparotomies at a Peripheral Hospital .Sch. J. App. Med. Sci., 2014; 2(5B):1591-1595

[11] Vipul Gurjar \& B. M. Halvadia \& R. P. Bharaney \& Vicky Ajwani \& S. M. Shah \& Samir Rai \& Mitesh Trivedi Study of Two Techniques for Midline Laparotomy Fascial Wound Closure Indian J Surg (March-April 2014) 76(2):91-94 DOI 10.1007/s12262012-0612-7

[12]PETER C. RICHARDS, M.D., * CHARLES M. BALCH, M.D., JOAQUIN S. ALDRETE, M.D A Randomized Prospective Study of 571 Patients Comparing Continuous vs. Interrupted Suture Techniques Ann.SUrg..FebrUarY1983 vol. 197

[13] Mirza SM, Hanif F, Khalid K, Ali AA, Chaudry AM. A prospective randomized trial of polypropylene and polydioxanone. Emir Med J 2003;21:45e8.

[14] Marwah S, Marwah N, Singh M, Kapoor A, Karwasra RK. Addition of rectus sheath relaxation inci- sions to emergency midline laparotomy for peritonitis to prevent fascial dehiscence. World J Surg. 2005; 29: 235-9. PMID: 15654663

[15] Docobo-Durantez F, Sacristán-Pérez C, Flor-Civera B, Lledó-Matoses S, Kreisler E, Biondo S. Randomized clinical study of polydioxanone and nylon sutures for laparotomy closure in high-risk patients. Cir Esp 2006;79:305e9.

[16] Seiler, Christoph M. MD*†; Bruckner, Thomas PhD*+; Diener, Markus K. MD*†; Papyan, Armine MD\$; Golcher, Henriette MD ; Seidlmayer, Christoph MD\|; Franck, Annette MD**; Kieser, Meinhard $\mathrm{PhDt}$; Büchler, Markus W. MD*†; Knaebel, Hanns-Peter $\mathrm{MD} \uparrow \dagger$ Interrupted or Continuous Slowly Absorbable Sutures For Closure of Primary Elective Midline Abdominal Incisions: A Multicenter Randomized Trial (INSECT: ISRCTN24023541) Annals of Surgery: April 2009 - Volume 249 - Issue 4 - pp 576-582 doi: 10.1097/SLA.0b013e31819ec6c8 Randomized Controlled Trials

[17] Badar Murtaza ${ }^{1}$, Naser Ali Khan ${ }^{1}$, Muhammad Ashraf Sharif ${ }^{2}$, Imran Bashir Malik ${ }^{3}$ and Asad Mahmood ${ }^{4}$ Modified Midline Abdominal Wound Closure Technique in Complicated/High Risk Laparotomies Journal of the College of Physicians and Surgeons Pakistan 2010, Vol. 20 (1): 37-41

[18]Bloemen A1, van Dooren P, Huizinga BF, Hoofwijk AG. Randomized clinical trial comparing polypropylene or polydioxanone for midline abdominal wall closure. 


\section{International Journal of Science and Research (IJSR) \\ ISSN (Online): 2319-7064}

Index Copernicus Value (2015): 78.96 | Impact Factor (2015): 6.391

Br J Surg. 2011 May;98(5):633-9. doi:

10.1002/bjs.7398. Epub 2011 Jan 19.

[19]P. Mallikarjun, Vinay Sagar Cheeti, Kiran Uske. "Comparison of Absorbable Extra Long Term Poly Hydroxy Butyrate Suture VS Non Absorbable (Polypropylene) Suture for Abdominal Wall Closure". Journal of Evidence based Medicine and Healthcare; Volume 2, Issue 29, July 20, 2015; Page: 42154225, DOI: $10.18410 / \mathrm{jebmh} / 2015 / 598$

[20] Mark A Carlson, MD,Kirk A Ludwig,MD \& Robert E Condon, MD, MS, Milwaukee, Wis. Ventral Hernia and other Complications of 1000 mid line incisions.SouthMed J April 1995 , Vol. 88, No. 4

[21]M.Murariu, N Bota, J Avram CAUSES OF RECURRENTINCISIONALHERNIATION Cercetãri Experimentale \& Medico-Chirurgicale Anul XV1 . Nr.2-3/2007 - Pag.142-146

[22] Spencer RJ1, Hayes KD, Rose S, Zhao Q, Rathouz PJ, Rice LW, Al-Niaimi Risk factors for early-occurring and late-occurring incisional hernias after primary laparotomy for ovarian cancer.AN. Obstet Gynecol. 2015 Feb;125(2):407-13. doi: 10.1097/AOG.0000000000000610.

[23] Sørensen, Lars Tue MD*; Hemmingsen, Ulla RN*; Kallehave, Finn MD*; Wille-Jørgensen, Peer MD, DmSci*; Kjærgaard, Johan MD, DmSci*; Møller, Lisbeth Nørgaard MS†; Jørgensen, Torben MD, DmSci† Risk Factors for Tissue and Wound Complications in Gastrointestinal Surgery April 2005 Volume 241 - Issue 4 - pp 654-658 